\title{
Health, Medicine, and Science in Asia
}

Over the last few decades, the Asian health landscape has gone through profound and dramatic changes. While access to healthcare shows severe inequalities from one country to the other and within countries, the region as a whole has positioned itself as a world player in the domain of health. Asia has become one of the primary destinations for medical and wellness travelers, attracted by specialized hospitals that follow international standards and provide first class treatments. The Asian pharmaceutical sector is a global competitor and therapeutic innovation is fueling new domestic healthcare markets. Biotech and clinical research are often equivalent to that seen in Europe and North America, while Asian traditional medicines have become a central feature of most contemporary societies, with a significant proportion of their industrial production aimed at export. New forms of therapeutic practices, knowledge and objects have emerged from the encounter of Asian medicine and biomedical science, giving way to braided concepts, products and tools, new epistemologies and understandings of the body, or again, revised regulatory schemes. Asian-born pandemics have contributed to redefine global health procedures, principles and meaning. The parallel evolution of these sectors coupled with structural transformations and new health policies, technological advancement and a low-cost workforce, have largely contributed to the renewal of Asian health services. This has not only modified national health policies and initiatives but also contributed to transforming the image of Asia in the realm of science and medicine. This book series seeks to bring attention to two decisive phenomena in these processes. The first concerns the uneasy relationship between increasing social disparities, the market and structural and technological developments in the field of health. The second phenomenon deals with global issues and their scales, as macro dynamics, transnationalism and local forms of globalization impact the production of health. This dual approach, embedded into the politics of healing, such as modes of governance and regulation, will help to explore the local fabric and global aspirations of Asian health. Studies from a variety of disciplines, from history to anthropology and the social study of science provide the backbone of the series.

\section{Series editor}

Laurent Pordié, National Center for Scientific Research (CNRS), Paris

\section{Editorial board}

Sienna Craig, Dartmouth College

Wen-Hua Kuo, National Yang-Ming University, Taipei

Alex McKay, International Institute of Asian Studies, Leiden

Projit Bihari Mukharji, University of Pennsylvania

Volker Scheid, University of Westminster, London 


\title{
Public Health in Asia during the COVID-19 Pandemic
}

Global Health Governance, Migrant Labour, and International Health Crises

\author{
Edited by \\ Anoma P. van der Veere, \\ Florian Schneider, and \\ Catherine Yuk-ping Lo
}


Cover image: with permission from Nick Potts

Cover design: Coördesign, Leiden

Lay-out: Crius Group, Hulshout

$\begin{array}{ll}\text { ISBN } & 9789463720977 \\ \text { e-ISBN } & 9789048555^{24} 6 \text { (pdf) } \\ \text { DOI } & 10.5117 / 9789463720977 \\ \text { NUR } & 870\end{array}$

(c) The authors / Amsterdam University Press B.V., Amsterdam 2022

All rights reserved. Without limiting the rights under copyright reserved above, no part of this book may be reproduced, stored in or introduced into a retrieval system, or transmitted, in any form or by any means (electronic, mechanical, photocopying, recording or otherwise) without the written permission of both the copyright owner and the author of the book.

Every effort has been made to obtain permission to use all copyrighted illustrations reproduced in this book. Nonetheless, whosoever believes to have rights to this material is advised to contact the publisher. 